National Trust in 1944 by his granddaughter, Miss M. T. Talbot. On its walls are portraits of a number of Fox Talbot's ancestors; but there is no portrait of Fox Talbot himself. The hundred and fiftieth anniversary of his birth will occur in February 1950, and a fund has therefore been opened to commission a portrait in oils for the South Gallery of Lacock Abbey opposite the window which was the subject of the earliest existing photograph, taken by Fox Talbot in 1835 and now in the Science Museum, London. A portrait of this character is considered to be preferable to a photograph, so as to accord with the others in the gallery. The honorary treasurer of the fund is Mr. Harold White, and donations should be sent to him at the Royal Photographic Society, 16 Princes Gate, London, S.W.7, and made payable to the "Fox Talbot Portrait Fund".

\section{Use of Glass Apparatus in the Laboratory and in Industry}

THE past fifteen years have seen a revolution in the uses of gloss apparatus both in the laboratory and in industrial plants. In particular, the adoption in the labofatory of standardized ground-glass joints has proxided an alternative to old arrays of corks and rybber tubing. Quickfit and Quartz, Ltd., started to produce such equipment in 1934 on the initiative Sir Graham Cunningham, chairman of Triplex Safety Glass Co., and until 1946 the works were wholly situated in the factory of the Triplex Co. at King's Norton, Birmingham. Quickfit and Quartz, Ltd., made gradual headway until 1939, and then, with the advent of the War, the abrupt cessation of laboratory supplies from Germany coupled with the greatly increased needs of research caused the output to go up ten-fold. Further expansion at King's Norton being impossible, in 1946 a new works was started at Stone in Staffordshire, which is now in production, and extensions are contemplated. With large pieces of glassware the question of annealing is extremely important, and special continuous-tunnel annealing. chambers are used, with polariscopes for viewing the strain contours by polarized light. The adoption by industry of glass for use in engineering plant was almost entirely a war-time development; but the value of glass in large condensers, heat-interchanges and for piping corrosive liquids, etc., is now univerrally recognized. Besides its use in the laboratory, glass has definitely taken its place as an important material in the whole field of engineering. The shop for production of industrial plant at Stone is only in part production, and the bulk of this work is still done at King's Norton. 326

\section{Journal of Experimental Botant}

THE Journal of Expefon intal Botany has been founded by the Society of Experimental Biology to provide in nodium top the publication of original research $\mathrm{n}^{\text {p plant }} \mathrm{p}^{\mathrm{j}}$ siology, biochemistry and bioAys cs andin fech related fields as experimental frot my. The editorial committee consists of Prof. A Ashby, Prof. T. A. Bennet-Clark, Prof. G. E. Blackman, Dr. R. Brown, Prof. F. G. Gregory, Dr. W. O. James, Prof. W. H. Pearsall, Dr. R. D. Preston and Prof. M. Thomas. The Journal will not be restricted to papers submitted by members of the Society, and contributions from research workers, both in Great Britain and abroad, will be considered. Manuscripts of papers submitted for publication should be addressed to the executive editor, Prof. T. A. Bennet-Clark, University of London, King's
College, Strand, London, W.C.2. Three numbers will comprise a volume, and they will appear at fourmonthly intervals, commencing in January 1950. The subscription price for three consecutive numbers is 35s., including postage. Single number 14s. net.

\section{Sugar Research Foundation: Awards}

THE fourth (1949) annual award of 5,000 dollars by the Sugar Restarch Foundation, Inc., New York, established by the Foundation to stimulate scientific studies of gagar as a food and as an industrial raw material with the aim of improving its usefulness, has been pade to Dr. Hermann O. L. Fischer, of the Unipersity of California, Berkeley, for his contributions to knowledge of the molecular structure of carbohydrates and his studies of glyceraldehyde, inositol and the nitromethane synthesis. Follow. ing the four annual awards of 1946-49 a grand prize of 25,000 dollars will be given in 1950 for the most significant discovery of the preceding five years. This prize will be awarded in recognition of discoveries, inventions or developments in the scientific or technological application of carbohydrates which contribute most significantly to an understanding of the functions of sugar (that is, sucrose), or its practical utilization, as a foodstuff or in its use in any other field of human activity. The award is open to any person, including the recipients of the four annual awards, and all entries should be submitted by February 1, 1950. Further details can be obtained from the Executive Secretary, National Science Fund of the National Academy of Sciences, 2101 Constitution Avenue, N.W., Washington 25, D.C.

\section{Exhibition: Medicine in History}

AN exhibition entitled "Medicine in History" will be opened on November 26 at the Glasgow Art Gallery and Museym, and will continue until the end of January. The exhibition will mark the three hundred and hftieth anniversary of the Royal Faculty of Physigians and Surgeons of Glasgow, founded by King James VI on November 29, 1599, by a chartor granted to Peter Lowe and Robert Hamiltone. Spocial emphasis has naturally been laid upon the Work of medical men who were Fellows of the Faculty, among whom may be mentioned William Cullen, Joseph Black, William Hunter, Lord Lister, Sir William Macewen and David Livingstone. Through the courtesy of a Glasgow firm, a reconstruction of a modern operating theatre has been arranged, for contrast with that of an operating theatre in the Glasgow Royal Infirmary in the late nineteenth century. The advances made in radiology in the same space of time are also illustrated. The history of dentistry is traced in examples lent by a Glasgow dentist, and a London collector has loaned pharmacy jars and apothecaries' mortars. The foundations of modern medicine can be seen in a series of historicel medical books. The exhibition has been made possible through the generosity and co-operation of institutions and private persons in Glasgow, Edinburgh and London in placing their valuable, and often irreplaceable, records and specimens at the disposal of the Corporation of the City of Glasgow.

\section{Colonial Service: Recent Appointments}

THE folletwing appointments in the Colonial Service have boon recently announced: J. Chattaway, agricultyal officer, Federation of Malaya; W. R. Mills, agricultural chemist, Uganda; C. C. Shapland, agricultural officer, Tanganyika; J. R. Scobie, 